УДК 351.439 .02

DOI: $10.15673 /$ fie.v12i1.1665

\author{
Дерев'янко О.Г. \\ доктор економічних наук, професор \\ Інститут післядипломної освіти \\ Національний університет харчових технологій \\ вул. Володимирська, 68, Київ, 01033 \\ E-mail: y.derevyanko@ pr-service.com.ua \\ ORCID ID: 0000-0002-1857-2862
}

\title{
КАПІТАЛІЗАЦІЯ ВИРОБНИКІВ ХАРЧОВИХ ПРОДУКТІВ В АСПЕКТІ ЗАБЕЗПЕЧЕННЯ ПРОДОВОЛЬЧОЇ БЕЗПЕКИ
}

У статті представлено результати визначення взаємозв'язку капіталізації вітчизняних харчових підприємств та продовольчої безпеки країни. Основною метою даної статті є наведення авторської аргументації щодо того, що цільова модель діяльності харчових підприємств, яка пов'язана із забезпеченням зростання їх капіталізації не є суперечливою до задач забезпечення продовольчої безпеки країни. Представленні у статті результати фракторного фрінансового аналізу капіталізації вітчизняних харчових підприємств на основі RE-моделі свідчать про те, що додана вартість бізнесу визначається спредом доходності реалізації харчових продуктів та обсягами їх продажу. Це мотивує менеджмент вітчизняних харчових підприємств фокусуватися на питаннях забезпечення найвищого рівня якості та конкурентоспроможності харчових продуктів, що відповідно вимагає розвитку їх ресурсної бази. Наведені розрахунки динаміки змін технологічного рівня розвитку виробничої бази вітчизняних харчових підприємств та рівня впровадження ними маркетингових інновацій є свідченням того, що орієнтація на високі фрінансово-економічні результати капіталоутворення зумовлює активізацію діяльності в забезпеченні викової якості харчових продуктів, а, відповідно, позитивно впливає на продовольчу безпеку країни.

Ключові слова: продовольча безпека, капіталізація, харчові підприємства, конкурентоспроможність, якість харчових продуктів.

This work is licensed under a Creative Commons Attribution 4.0 International License http://creativecommons.org/licenses/by/4.0/

Постановка проблеми та її зв'язок з важливими науковими та практичними завданнями. Проблематика продовольчої безпеки є однією з найбільш обговорюваних як у науковому так і бізнестоваристві, що зумовлено, перш за все, тим, що продовольство $\epsilon$ базовим продуктом, який необхідний для існування та відтворення людства. Актуалізація дослідження питань продовольчої безпеки може бути аргументована короткою цитатою Ж.-Ж. Русо, який наголошував на тому, що «...єдиний засіб утримати державу у стані незалежності від будь-кого - це сільське господарство. Володій ви хоч всіма багатствами світу, якщо вам нічим харчуватися - ви залежите від інших». I науковці, і практики продовольчу безпеку розглядають як складову забезпечення економічної та національної безпеки будь-якої країни, при цьому варто зробити акцент на тому, що іiї просторовий рівень $є$ набагато ширшим та глобальнішим.

Категорія «продовольча безпека» увійшла у науковий оборот у 1974 р., в результаті їі легалізації на Всесвітній продовольчій конференції, що відбулася у Римі у результаті прийняття «Загальної декларації про ліквідацію голоду та недоїдання». Сьогодні, технологічний розвиток та світові глобалізаційні виклики розширюють змістовний контекст проблематики продовольчої безпеки, який описується питаннями забезпечення безпечності харчової продукції, що актуалізує дослідження питань промислової переробки сільськогосподарських продуктів харчовими підприємствами. У такій змістовній постановці питання забезпечення продовольчої безпеки доцільно розглядати у площині капіталоутворення, рівень якості якого безпосередньо визначає ціннісні результати у вигляді споживчої цінності пропонованих продуктів харчування.

Аналіз останніх публікацій по проблемі. Дослідження питань продовольчої безпеки в аспектах забезпечення національної та економічної безпеки представлено у наукових працях зарубіжних (Г. Бокела, Е. Бухвальда, Л. Вайнгертнера, М. ГерстерБентая, У. Ліферта, О. Мамедова, В. Сенчагова, А. Татаркіна, ін.) та вітчизняних вчених (М. Бабієнко, О. Витвицької, В. Гейця, Л. Гур'янової, М. Залізнюка, М. Кизима, Т. Клебанової, О. Кардаш, М. Кулайця, П. Лайко, О. Ляшенко, I. Манзій, Т. Пономаренко, А. Пілька, Л. Фролової, С. Щербини, ін.). Питання капіталотворення в аспекті забезпечення продовольчої безпеки актуалізовані у наукових публікаціях М. Залізнюка, Л. Киш, І. Кошкалда, Т. Пономаренко, Л. Шелудька, при цьому комплексних завершених досліджень у даному напрямку не представлено. 
Формулювання цілей дослідження. Основною метою даної статті є представлення результатів авторських досліджень в аспекті встановлення взаємозв'язку між цільовою діяльністю вітчизняних харчових підприємств, що орієнтовані на забезпечення зростання їх капіталізації та вирішенням більш глобальної задачі у вигляді дотримання належного рівня продовольчої безпеки. На думку автора, дані цілі не $є$ суперечними, а відповідна аргументація представлена у змістовних межах даної наукової статті.

У ході даного дослідження було використано такі загальнонаукові та спеціальні методи: наукового узагальнення - для визначення основних характеристик продовольчої безпеки; методи параметризаціїпри оцінюванні результатів капіталоутворення харчових підприємств; вартісного, фінансового та факторного аналізу - при оцінюванні факторів впливу на капіталізацію харчових підприємств; таксономічного аналізу - для визначення рівня розвитку виробничої бази вітчизняних харчових підприємств та рівня впровадження ними маркетингових інновацій; метод причинно-наслідкових зв'язків - у процесі аргументації взаємозв'язку капіталізації харчових підприємств та рівнем продовольчої безпеки.

Виклад основних результатів та їх обгрунтування. Критичний аналізу наукових джерел та нормативно правових документів різних країн [1-8] дозволяє виділити та упорядкувати основні характеристики, що визначають зміст продовольчої безпеки:

- доступність продуктів харчування (фізична та економічна доступність);

- достатність раціону харчування;

- якість та безпечність продовольства;

- створення необхідних резервів продовольчих продуктів;

- забезпечення продовольчої незалежності країни.
Серед даних характеристик однією з ключових та актуальних за сучасних умов $є$ забезпечення якості та безпечності продовольчих продуктів, що зміщує аспект досліджень не тільки у площину сільськогосподарського виробництва, а і промислової переробки, яку безпосередньо здійснюють харчові підприємства Харчова промисловість України протягом останніх десяти років характеризується зростаючими тенденціями як у кількісному, так і якісному вимірі, а вітчизняний ринок продовольства $є$ висококонкурентним. Саме посилення конкуренції на ринку продуктів харчування стимулює виробників реалізовувати заходи, технологічного, організаційного, управлінського, ін. характеру, що спрямовані, перш за все, на підвищення якості та конкурентоспроможності продукції, що у кінцевому підсумку впливає на економічні результати діяльності.

Економічні результати, незалежно від того, у якій формі вони представлені, $\epsilon$ наслідками процесів капіталоутоворення, які сьогодні мають свою специфіку, зумовлену тенденціями розвитку бізнессередовища господарювання, у тому числі і харчових підприємств. Так, здатність забезпечувати формування потоків цінності для стейкхолдерів, що перетворюються на додану вартість бізнесу у більшому ступені стає залежною не стільки від матеріалізованих та фінансових форм капіталу, скільки від рівня розвитку його інтелектуальної складової, яка безпосередньо визначає якість управлінських рішень та отримані результати.

Факторний аналіз результатів капіталоутворення вітчизняних харчових підприємств (табл. 1) свідчить про те, що базовим фактором, що їх визначає $\epsilon$ спред доходності реалізації продукції та обсяги продажу.

Таблиця 1

Показники економічного зростання вітчизняних харчових підприємств за критерієм капіталізації"

\begin{tabular}{|c|c|c|c|c|c|c|c|c|c|}
\hline \multirow{2}{*}{ Показники } & \multicolumn{9}{|c|}{ Роки } \\
\hline & 2010 & 2011 & 2012 & 2013 & 2014 & 2015 & 2016 & 2017 & 2018 \\
\hline \multicolumn{10}{|l|}{ 1. Капіталізація: } \\
\hline - мЛн.грн & 38513 & 45774 & 58602 & 67903 & 45902 & 39106 & 46779 & 74786 & 106769 \\
\hline $\begin{array}{l}\text { - темп приросту } \\
\text { (зменш.), \% до по- } \\
\text { переднього року }\end{array}$ & 14,76 & 18,85 & 28,03 & 15,87 & $-32,40$ & $-14,81$ & 19,62 & 59,87 & 42,77 \\
\hline $\begin{array}{l}\text { 2. Темп приросту } \\
\text { (зменш) чистих акти- } \\
\text { вів за балансовою } \\
\text { вартістю, \% до попе- } \\
\text { реднього року }\end{array}$ & 21,29 & 19,98 & 18,14 & 19,93 & 2,34 & $-12,02$ & $-2,81$ & 21,08 & 38,30 \\
\hline $\begin{array}{l}\text { 3. Додана вартість } \\
\text { (остаточний чистий } \\
\text { прибуток), млн.грн }\end{array}$ & -4877 & -6286 & -2903 & -5861 & -29588 & -27313 & -17773 & -3375 & -1326 \\
\hline $\begin{array}{l}\text { 4. Спред доходності } \\
\text { реалізації продукції, \% }\end{array}$ & $-2,53$ & $-2,83$ & $-1,14$ & $-2,24$ & $-9,78$ & $-6,86$ & $-3,84$ & $-0,62$ & $-0,22$ \\
\hline $\begin{array}{l}\text { 5. Рентабельність } \\
\text { (збитковість) реаліза- } \\
\text { ції продукції, \% }\end{array}$ & 1,16 & 1,04 & 2,82 & 2,50 & $-5,59$ & $-4,16$ & $-1,62$ & 1,62 & 2,63 \\
\hline
\end{tabular}


Продовження табл. 1

\begin{tabular}{|l|c|c|c|c|c|c|c|c|c|}
\hline \multicolumn{1}{|c|}{ Показники } & \multicolumn{9}{|c|}{ Роки } \\
\cline { 2 - 10 } & 2010 & 2011 & 2012 & 2013 & 2014 & 2015 & 2016 & 2017 & 2018 \\
\hline $\begin{array}{l}\text { 9. Коефіціснт відпові- } \\
\text { дності фактичного } \\
\text { рівня рентабельності } \\
\text { реалізації продукції } \\
\text { критичному значенню }\end{array}$ & 0,31 & 0,27 & 0,71 & 0,53 & 0,00 & 0,00 & 0,00 & 0,72 & 0,92 \\
\hline $\begin{array}{l}\text { 10. Темп приросту } \\
\text { виручки від продажу } \\
\begin{array}{l}\text { продукції, \% до попе- } \\
\text { реднього року }\end{array}\end{array}$ & 21,00 & 15,19 & 14,42 & 2,88 & 15,51 & 31,62 & 16,18 & 18,59 & 7,56 \\
\hline $\begin{array}{l}\text { 11. Рентабельність } \\
\text { (збитковість) власно- } \\
\text { го капіталу, \% }\end{array}$ & 5,16 & 4,42 & 11,68 & 8,85 & $-22,39$ & $-24,92$ & $-11,63$ & 11,38 & 14,37 \\
\hline
\end{tabular}

*Розраховано автором за даними [9]

Так, протягом 2010 - 2018 рр. спред прибутковості реалізації продукції був від'ємною величиною, що пояснюється збитковістю діяльності у 2014 - 2016 pp., та недостатністю фактичного рівня прибутковості продажу продукції критичним значенням. Причини $\epsilon$ різними, від високого рівня поточних витрат на виро- бництво та реалізацію продукцію, до низьких обсягів продажу в силу дії різних обставин. Щодо обсягів продажу продукції, то спостерігається стійка тенденція зростання як в цілому по харчовій промисловості, так і у розрізі основних виробництв (табл. 2).

Таблиця 2

Показники господарської діяльності галузей харчової промисловості України*

\begin{tabular}{|c|c|c|c|c|c|c|c|c|c|c|}
\hline $\mathscr{0}$ & 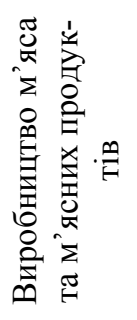 & 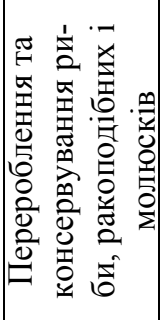 & 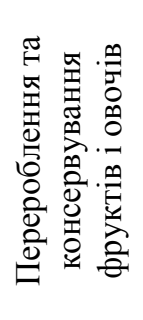 & 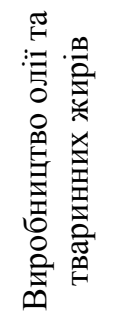 & 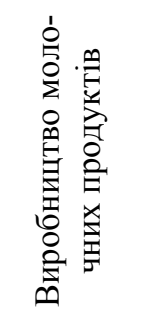 & 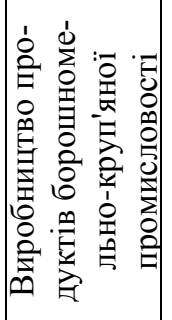 & 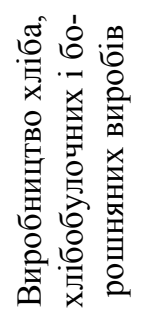 & 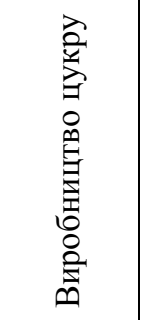 & 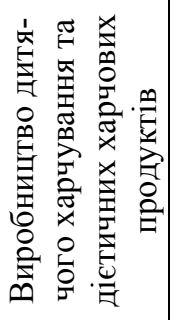 & 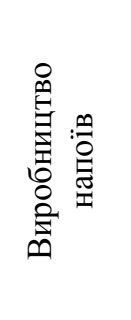 \\
\hline \multicolumn{11}{|c|}{ Частка у загальному обсязі реалізації продукції харчової промисловості, \% } \\
\hline 2010 & 8,27 & 0,92 & 4,18 & 19,12 & 13,00 & 4,03 & 4,91 & 2,81 & 0,09 & 16,24 \\
\hline 2011 & 9,62 & 0,78 & 4,42 & 17,99 & 11,58 & 4,03 & 4,88 & 3,55 & 0,10 & 16,16 \\
\hline 2012 & 10,57 & 1,17 & 4,42 & 16,74 & 11,28 & 3,60 & 4,55 & 3,00 & 0,12 & 16,45 \\
\hline 2013 & 10,87 & 1,05 & 4,70 & 20,62 & 11,79 & 3,91 & 4,40 & 2,38 & 0,13 & 15,29 \\
\hline 2014 & 9,63 & 1,02 & 4,70 & 28,17 & 10,35 & 3,18 & 3,65 & 2,69 & 0,15 & 11,20 \\
\hline 2015 & 10,08 & 1,01 & 3,97 & 24,89 & 9,49 & 4,43 & 3,59 & $\mathrm{x}$ & $\mathrm{x}$ & 11,90 \\
\hline 2016 & 8,15 & 1,18 & 3,46 & 34,18 & 8,64 & 4,80 & 3,51 & $\mathrm{x}$ & $\mathrm{x}$ & 10,76 \\
\hline 2017 & 13,18 & 1,17 & 3,43 & 30,08 & 9,54 & 4,56 & 3,12 & 2,87 & 0,12 & 9,87 \\
\hline 2018 & 12,97 & 1,37 & 3,76 & 29,69 & 9,97 & \begin{tabular}{|l|l|}
3,55 \\
\end{tabular} & 3,28 & 2,40 & 0,14 & 10,76 \\
\hline \multicolumn{11}{|c|}{ Темпи приросту обсягів реалізації продукції, \% до попер.року } \\
\hline 2011 & 35,30 & $-1,56$ & 22,79 & 9,38 & 3,52 & 16,13 & 15,31 & 47,00 & 24,23 & 15,62 \\
\hline 2012 & 29,56 & 77,27 & 17,99 & 9,74 & 14,80 & 5,32 & 9,99 & $-0,62$ & 44,79 & 20,04 \\
\hline 2013 & 8,35 & $-5,06$ & 11,98 & 29,83 & 10,21 & 14,52 & 1,96 & $-16,14$ & 12,43 & $-1,99$ \\
\hline 2014 & 1,43 & 10,57 & 14,51 & 56,39 & 0,55 & $-6,83$ & $-4,96$ & 29,17 & 29,54 & $-16,11$ \\
\hline 2015 & 32,65 & 25,09 & 7,12 & 11,91 & 16,02 & 76,20 & 24,32 & $\mathrm{x}$ & $\mathrm{x}$ & 34,52 \\
\hline 2016 & $-0,48$ & 43,89 & 7,07 & 69,02 & 12,08 & 33,28 & 20,51 & $\mathrm{x}$ & $\mathrm{x}$ & 11,26 \\
\hline 2017 & 95,20 & 20,48 & 19,87 & 6,30 & 33,36 & 14,75 & 7,48 & $\mathrm{x}$ & $\mathrm{x}$ & 10,78 \\
\hline 2018 & 4,31 & 23,48 & 16,25 & 4,59 & 10,84 & $-17,34$ & 11,43 & $-11,39$ & 20,73 & 15,54 \\
\hline \multicolumn{11}{|c|}{ Чистий прибуток, тис.грн } \\
\hline 2010 & -21836 & -76481 & -103590 & 227249 & -1063508 & 81131 & 154990 & -203013 & -11657 & 389289 \\
\hline 2011 & -35329 & -67577 & -40032 & 522707 & -669717 & -630255 & -29525 & -1093873 & 11624 & 655601 \\
\hline 2012 & -74442 & -31918 & -43834 & 540050 & 931249 & -111882 & -228075 & -716455 & 31769 & 1641369 \\
\hline 2013 & -161240 & 258 & 18470 & 473636 & 693855 & 37383 & 348129 & -907493 & 11659 & 1048132 \\
\hline
\end{tabular}


Продовження табл. 2

\begin{tabular}{|c|c|c|c|c|c|c|c|c|c|c|}
\hline Q & 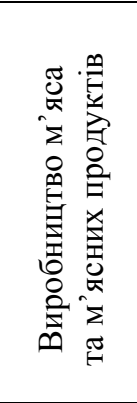 & 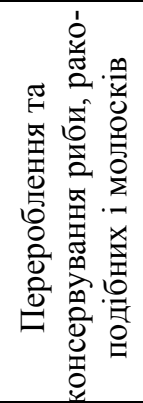 & 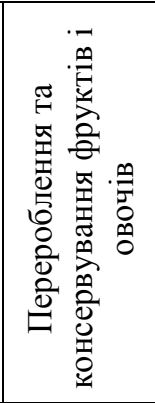 & 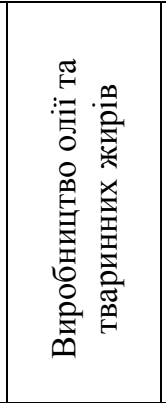 & 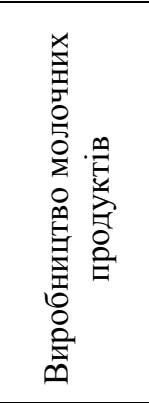 & 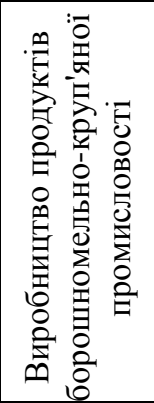 & 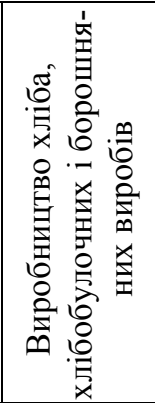 & 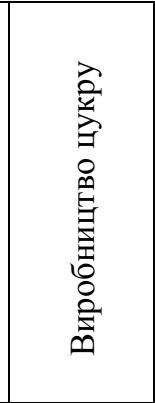 & 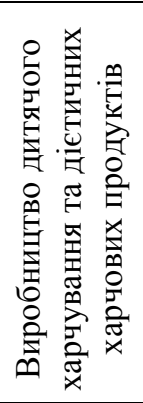 & 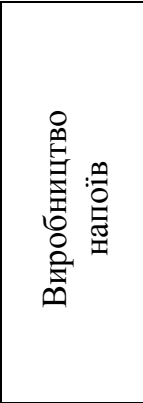 \\
\hline 2014 & -109074 & -164379 & -2216025 & \begin{tabular}{|l|}
-7129410 \\
\end{tabular} & -1165478 & -518481 & -40492 & -2126194 & 12693 & -2761485 \\
\hline 2015 & 41793 & 45913 & -1162429 & -10517598 & -1905302 & 29108 & -1404584 & -344448 & 18295 & -2142104 \\
\hline 2016 & 311603 & -88620 & -565121 & -5541345 & \begin{tabular}{|l|}
-497084 \\
\end{tabular} & 30162 & -220423 & 303791 & 56115 & 768907 \\
\hline 2017 & 1338965 & -33862 & 680780 & -2180565 & 1011197 & -3962207 & 135665 & 521377 & 39781 & 1311077 \\
\hline 2018 & 1003547 & 148312 & 749126 & -254465 & 1284374 & 418576 & 80722 & -1447485 & 38284 & 1657215 \\
\hline \multicolumn{11}{|c|}{ Продуктивність активів, грн./грн } \\
\hline 2013 & 0,86 & 1,30 & 0,94 & 1,17 & 1,02 & 1,37 & 1,61 & 0,56 & 1,41 & 0,97 \\
\hline 2014 & 0,86 & 1,69 & 0,74 & 1,35 & 0,96 & 1,33 & 1,63 & 0,65 & 1,46 & 0,86 \\
\hline 2015 & 1,00 & 2,02 & 0,82 & 1,14 & 1,18 & 1,04 & 1,80 & $\mathrm{x}$ & $\mathrm{x}$ & 1,00 \\
\hline 2016 & 0,92 & 2,23 & 0,84 & 1,38 & 1,28 & 1,17 & 1,78 & $\mathrm{x}$ & $\mathrm{x}$ & 1,01 \\
\hline 2017 & 1,14 & 1,89 & 0,85 & 1,42 & 1,58 & 1,19 & 1,66 & 0,96 & 1,82 & 1,15 \\
\hline 2018 & 1,13 & 1,76 & 0,93 & 1,39 & 1,65 & 1,19 & 1,79 & 0,84 & 1,61 & 1,21 \\
\hline \multicolumn{11}{|c|}{ Частка активів у їх загальній величині по харчовій промисловості, \% } \\
\hline 2013 & 13,67 & 0,88 & 5,43 & 19,20 & \begin{tabular}{|l|}
12,60 \\
\end{tabular} & \begin{tabular}{|l|}
3,09 \\
\end{tabular} & 2,97 & 4,65 & 0,10 & 17,21 \\
\hline 2014 & 12,05 & 0,65 & 6,89 & 22,57 & 11,68 & 2,58 & 2,42 & 4,47 & 0,11 & 14,13 \\
\hline 2015 & 10,96 & 0,54 & 5,27 & 23,82 & 8,74 & 4,65 & 2,16 & 3,66 & 0,13 & 12,98 \\
\hline 2016 & 9,58 & 0,57 & 4,44 & 26,89 & 7,30 & 4,42 & 2,13 & 3,04 & 0,07 & 11,50 \\
\hline 2017 & 14,35 & 0,77 & 5,01 & 26,29 & 7,48 & 4,72 & 2,33 & 3,68 & 0,08 & 10,65 \\
\hline 2018 & 14,32 & 0,97 & 5,04 & 26,64 & 7,54 & 3,71 & 2,28 & 3,56 & 0,11 & 11,06 \\
\hline
\end{tabular}

У структурі реалізації харчових продуктів найбільшою є частка олії та тваринних жирів, яка у 2018 p. становила $29,69 \%$, при цьому частка активів від загальної величини по харчовим підприємствам 26,64\%. Продуктивність праці у оліє-жировій промисловості хоча і $є$ не найбільшою серед харчових підприємств, але має зростаючу динаміку порівняно 3 2013 р. Негативними є зміни фінансових результатів у вигляді прибутку. Так, протягом 2014 - 2018 рр. підприємства галузі були збитковими.

32017 року другу рейтингову позицію у структурі виробництва та реалізації продуктів харчової промисловості займає м'ясопереробна промисловість, частка якої зросла з 8,27\% у 2010 р. до 12,97\% у 2018 p. Частка накопичених активів у їх загальній величині по харчові промисловості складає 14,32\%, а продуктивність праці зросла з 2013 по 2018 роки у 1,31 рази. Починаючи 32015 р. м'ясопереробні підприємства $\epsilon$ прибутковими, а обсяги реалізації у 2018 р. порівняно з 2010 р. зросли у 5,18 рази. У рейтингу ТОП-100 найдорожчих брендів України 5 відносяться до м'ясопереробної промисловості [10].

Більшою за $10 \%$ є частка реалізації напоїв у загальній структурі продажу продуктів харчової промисловості, а кількість представлених брендів у рейтингу ТОП-100 найдорожчих брендів України - 22. Обсяги продажу напоїв у 2018 р. порівняно з 2010 р. зросли у 2,2 рази, активів - у 1,3 рази, а діяльність характеризувалася прибутковістю (крім 2014 - 2015 pp.).

Варто зазначити, що протягом 2010 - 2018 pp. обсяг капіталовкладень становив 146,3 млрд.грн., a їх частка у харчовій промисловості порівняно із іншими переробними підприємствами є найбільшою і перевищує 15\% від загальнопромислового обсягу. Незважаючи на значну кількість невирішених проблем технологічний рівень виробництва на харчових підприємствах зростає (рис. 1), що безпосередньо відображається на якості харчових продуктів та їх конкурентоспроможності (рис. 2).

Так, рівень впровадження НАCCP на харчових підприємствах у 2017 р. порівняно з 2011 р. збільшився у 3,6 рази; технологічність виробництва зросла у 1,38 рази; спостерігається зростання рівня як лабораторної якості продукції, так і оцінки якості споживачів. Підприємства, що демонструють зростаючу динаміку показників конкурентоспроможності та фінансово-економічних результатів відрізняються тим, що на них щорічно збільшуються маркетингові бюджети та витрати на здійснення комунікацій зі стейкхолдерами бізнесу.

Таким чином, забезпечення зростання якісного рівня капіталоутворення, пріоритетною сферою якого $\epsilon$ нематеріальні види капіталу, безпосередньо визначає якість та безпечність продовольства, як кінцевого результату, що характеризує функціональний аспект діяльності харчових підприємств. 


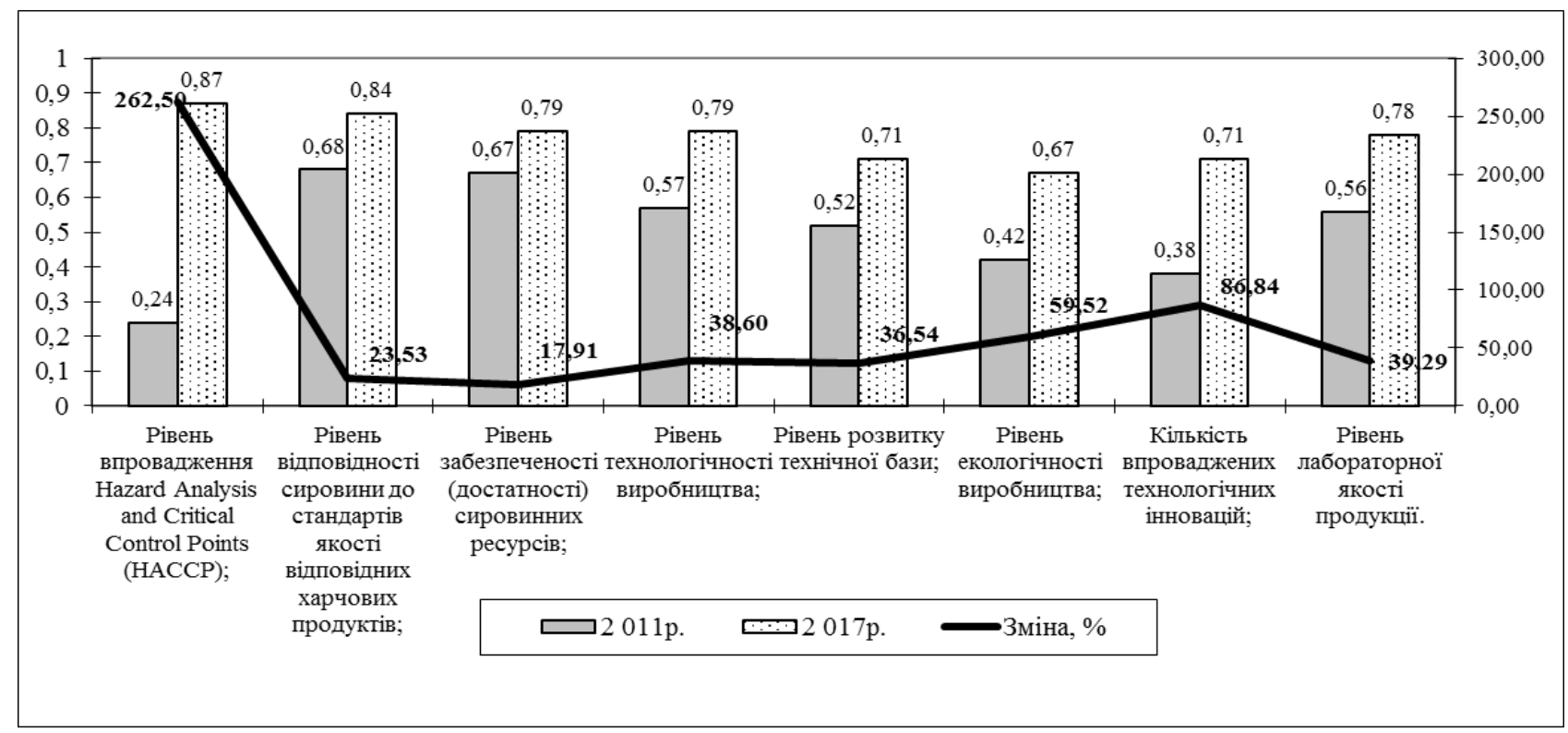

Рис. 1. Показники рівня розвитку виробничої бази харчових підприємств у 2011 - 2017 рр."

*складено автором на основі результатів узагальнення експертних оцінок 24 харчових підприємств

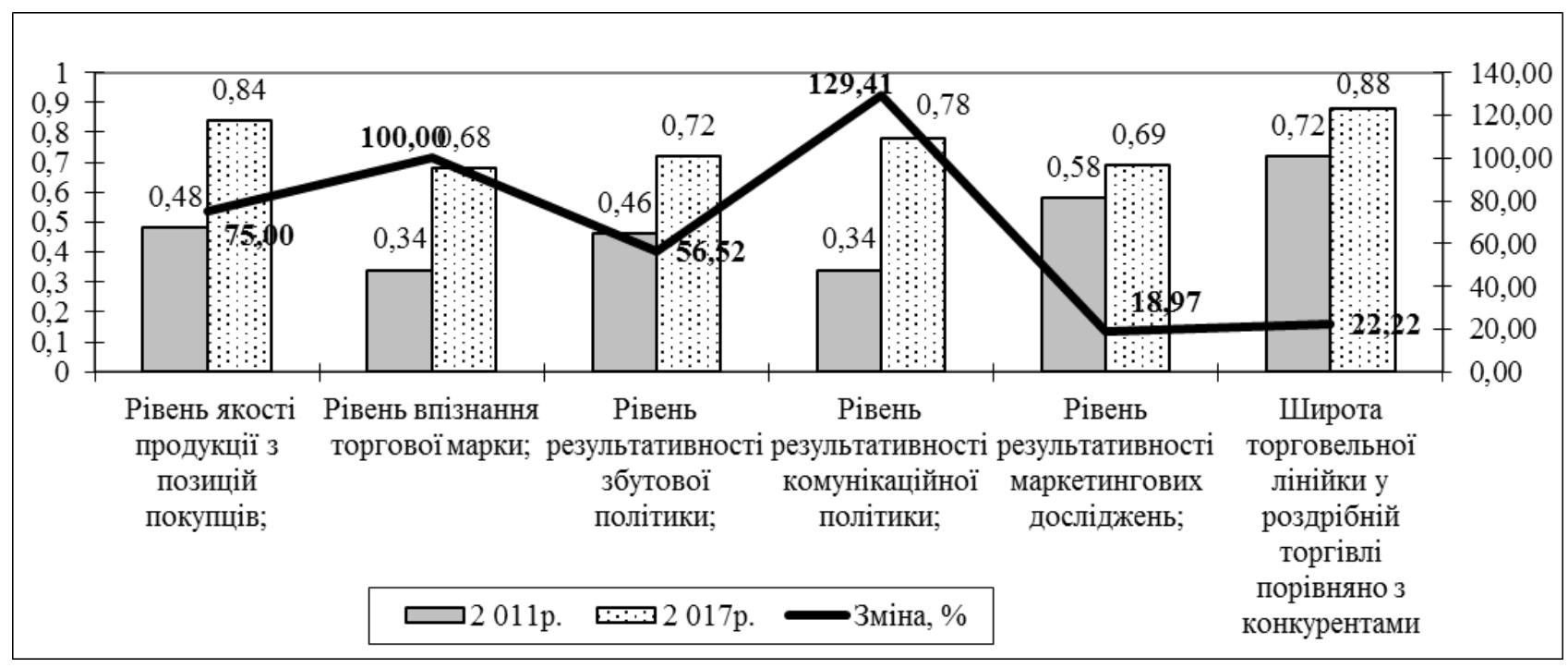

Рис. 2. Рівень впровадження маркетингових інновацій у практиці діяльності вітчизняних харчових підприсмств" *складено автором на основі результатів узагальнення експертних оцінок 24 харчових підприємств

Висновки та перспективи подальших досліджень. Діяльність харчових підприємств характеризується специфічністю яка полягає у необхідності дотримання високих санітарно-гігієнічних, екологічних вимог як до продуктів харчування, так і їх виробництва; обмежені терміни та спеціальні умови зберігання та транспортування; обмеження з боку використання окремих видів сировини; індивідуалізація попиту з урахуванням особливостей певних локальних ринків, ін. При цьому основною перевагою даною бізнесу $є$ те, що попит на продукти харчування $є$ стабільним, а в умовах українських реалій спостерігається динаміка його зростання на більш якісну продук- цію, що стимулює виробників до забезпечення більш високого технологічного рівня капіталотворення та визначає якість та безпечність продовольства в цілому. Сьогодні, забезпечення високого рівня фінансових результатів у вигляді капіталізації стає можливим лише за умови постійної роботи з технологіями виробництва; вдосконалення асортименту виробленої продукції з урахуванням уподобань споживачів та їх ментальними установками та способом життя; забезпечення екологічних стандартів і норм не тільки у сфері виробництва, а і транспортування та збуту, що в свою чергу зумовлює зростання рівня продовольчої безпеки країни в цілому. 


\title{
Література
}

1. Римская Декларация о всемирной продовольственной безопасности и действий Всемирной встречи на высшем уровне по проблемам продовольствия (13 ноября 1996 г., м. Рим) / Продовольственная и с и сельскохозйственная организация Объединённых Haций. URL: http:// http://observer.materik.ru/observer/N3-4_97/019.htm (дата звернення: 10.01.2020)

2. Алєксєєва Я. Наукові засади визначення продовольчої безпеки // Ефективність державного управління. 2015. Вип. 42. С. 100-107.

3. Волченко Н. В. Продовольча безпека: теоретичні аспекти та реалії сьогодення: монографія. Система національного менеджменту в контексті інтеграційного виміру. Суми: ПП Вінниченко М. Д., ФОП Литовченко Є. Б., 2014. С. 38-57.

4. Ильина 3. М. Продовольственная безопасность: теория, методология, практика. Минск: ГНУ «Ин-т экономики НАН Белорусии», 2007. 230 с.

5. Лисецький А. С. Продовольча безпека України: теорія, методологія, емпіричний аналіз. НАН України. Рада по вивч. продукт. сил України. Київ: Оріяни, 2005. 373 с.

6. Проскура В. Ф. Формування системи моніторингу продовольчої безпеки регіону // Вісник КрНУ імені Михайла Остроградського. 2015. Вип. 3. С. 63-67.

7. Страшинська, Л. В. Основні критерії оцінки рівня продовольчої безпеки України та стратегічні напрями її підвищення // Агросвіт. 2011. № 20. С. 6-11.

8. Фролов А. Понятійно-категоріальний апарат державного регулювання забезпечення продовольством населення // Вісник державної служби України. 2011. № 3. С. 1115

9. Державний комітет статистики України: [Веб сайт]. Київ, 2020. URL: http://www.ukrstat.gov.ua/ (дата звернення: 10.01.2020)

10. ТОП-100 найдорожчих брендів України - рейтинг HB: [Веб сайт]. URL: https://nv.ua/ukr/biz/markets/reyting-ukrajinskih-brendiv-top-100-naydorozhchih-torgovih-marok-ukrajini-noviniukrajini-50055102.html (дата звернення: 10.01.2020)

Стаття надійшла 20.01.2020

Стаття прийнята до друку 3.02.2020 Доступно в мережі Internet 31.03.20

\author{
Деревянко О.Г. \\ доктор экономических наук, профессор \\ Институт последипломного образования \\ Национальный университет пищевых технологий \\ улица Владимирская, 68, Киев, Украина,01033 \\ E-mail: y.derevyanko @ pr-service.com.ua \\ ORCID ID: 0000-0002-1857-2862
}

\section{КАПИТАЛИЗАЦИЯ ПРОИЗВОДИТЕЛЕЙ ПИЩЕВЫХ ПРОДУКТОВ В АСПЕКТЕ ОБЕСПЕЧЕНИЯ ПРОДОВОЛЬСТВЕННОЙ БЕЗОПАСНОСТИ}

\footnotetext{
В статье представлены результаты определения взаимосвязи капитализации отечественных пищевых предприятий и продовольственной безопасности страны. Основной целью данной статьи является представление авторской аргументации относительно того, что целевая модель деятельности пищевых предприятий, связанная с обеспечением роста их капитализации, не является противоречивой к задачам обеспечения продовольственной безопасности страны. В ходе проведения исследования были использованы следующие методы: научного обобщения, параметризации, стоимостного, фринансового таксономического и фракторного анализа, метод причинно-следственных связей. Использование данных методов позволило получить такие результаты, которые подтвердили авторскую рабочую гипотезу, которая была сформулирована в начале исследования. Представленные в статье результаты факторного фринансового анализа капитализации отечественных пищевых предприятий на основе $R E$-модели свидетельствуют о том, что добавленная стоимость бизнеса определяется спрэдом доходности реализации пищевых продуктов и объемами их производства и продаж. Это мотивирует менеджмент отечественных пищевых предприятий фокусироваться на вопросах обеспечения высокого уровня качества и конкурентоспособности пищевых продуктов, соответственно требует развития их ресурсной базы. Приведенные расчеты динамики изменений технологического уровня развития производственной базы отечественных пищевых предприятий и уровня внедрения ими мар-
} 
кетинговых инноваций является свидетельством того, что ориентация на высокие фринансовоэкономические результаты капиталообразования обусловливает активизацию деятельности в обеспечении более високого уровня качества пищевых продуктов, а, соответственно, положительно влияет на продовольственную безопасность страны. Научная новизна данного исследования заключается в актуализации проблематики взаимосвязи между финансово-экономическими результатами капиталообразования на пищевых предприятиях и уровнем продовольственной безопасности страны. Полученные практические результаты являются подтверждением авторской рабочей гипотезы относительно того, что рост капитализации пищевых предприятий возможно только за счет роста качества пищевых продуктов и наращивание их объемов производства и продаж, что непосредственно положительно влияет на продовольственную безопасность страны.

Ключевые слова: продовольственная безопасность, капитализация, пищевые предприятия, конкурентоспособность, качество пищевых продуктов.

\author{
Derevyanko 0. \\ Doctor of Economics, Professor, \\ Institute of Postgraduate Education \\ National University of Food Technology \\ 68 Volodymyrska Street, Kyiv, Ukraine, 01033 \\ Email: y.derevyanko @ pr-service.com.ua \\ ORCID ID: 0000-0002-1857-2862
}

\title{
CAPITALIZATION OF FOOD PRODUCERS IN THE ASPECTS OF FOOD SAFETY
}

The article presents the results of determining the relationship of capitalization of domestic food enterprises and food security of the country. The main purpose of this article is to represent the author's argument regarding the fact that the target model of activity of food companies, which is associated with the growth of their capitalization, is not contradictory to the objectives of ensuring food security of the country. In the course of their search the following methods were used: scientific generalization, parameterization, cost, financial taxonomy and factor analysis, the method of causality. The use of these methods allowed us to obtain results that confirmed the author's working hypothesis, which was formulated at the beginning of the study. Presented in the article results of the factorial financial analysis of capitalization of domestic food companies based on the RE model indicate that the added value of the business is determined by the yield spread of food sales and their volume of production sales. It motivates the management of domestic food enterprises to focus on ensuring a high level of quality and competitiveness of food products, which consequently requires the development of their resource base. The calculations of the dynamics of changes of the technological level of development of the productive base of the domestic food enterprises and the level of implementation of marketing innovations is the evidence that the focus on high financial-economic results of capital formation stipulates in increased activity in providing high quality food products, and, accordingly, has a positive effect on food security of the country. The scientific novelty of this research lies in mainstreaming the linkages between the financial and economic results of capital formation in food industry and food security level of the country. Practical results are a proof of the author's working hypothesis, that the growth of capitalization of food companies is possible only by providing qualitative food products and increasing the volume of production and sales, which directly has a positive effect on food security of the country.

Key words: food security, capitalization, food companies, competitiveness, quality of food products.

\section{References}

1. Rimskaya Deklaratsiya o vsemirnoy prodovolstvennoy bezopasnosti i deystviy Vsemirnoy vstrechi na vyisshem urovne po problemam prodovolstviya. (1996). Retrieved January 10, 2020, from

http://observer.materik.ru/observer/N3-4_97/019.htm

2. Alieksieieva, Ya. (2015). Naukovi zasady vyznachennia prodovolchoi bezpeky. Efektyvnist Derzhavnoho Upravlinnia, (42), 100-107.

3. Volchenko, N. V. (2014). Prodovolcha bezpeka: teoretychni aspekty ta realii sohodennia. In Systema natsionalnoho menedzhmentu v konteksti intehratsiinoho vymiru (pp. 38-57). Sumy: PP Vinnychenko M. D., FOP Lytovchenko Ye. B. 
4. Ilina, Z. M. (2007). Prodovolstvennaya bezopasnost: teoriya, metodologiya, praktika. Minsk: GNU «In-t ekonomiki NAN Belorusii».

5. Lysetskyi, A. S. (2005). Prodovolcha bezpeka Ukrainy: teoriia, metodolohiia, empirychnyi analiz. Kyiv: Oriiany.

6. Proskura, V. F. (2015). Formuvannia systemy monitorynhu prodovolchoi bezpeky rehionu. Visnyk KrNU Imeni Mykhaila Ostrohradskoho, (3), 63-67.

7. Strashynska, L. V. (2011). Osnovni kryterii otsinky rivnia prodovolchoi bezpeky Ukrainy ta stratehichni napriamy yii pidvyshchennia. Ahrosvit, (20), 6-11.

8. Frolov, A. (2011). Poniatiino-katehorialnyi aparat derzhavnoho rehuliuvannia zabezpechennia prodovolstvom naselennia. Visnyk Derzhavnoi Sluzhby Ukrainy, (3), 11-15.

9. Derzhavnyi komitet statystyky Ukrainy. (2020). Retrieved January 10, 2020, from http://www.ukrstat.gov.ua/

10. TOP-100 naidorozhchykh brendiv Ukrainy - reitynh NV. (2019). Retrieved January 10, 2020, from https://nv.ua/ukr/biz/markets/reyting-ukrajinskih-brendiv-top-100-naydorozhchih-torgovih-marok-ukrajini-noviniukrajini-50055102.html

Received 20 January 2020

Approved 3 February 2020

Available in Internet 31.03.20

Цитування згідно ДСТУ 8302:2015

Дерев'янко О.Г. Капіталізація виробників харчових продуктів в аспекті забезпечення продовольчої безпеки // Економіка харчової промисловості. 2020. Т.12, вип. 1. С. 20-27. doi: 10.15673/fie.v12i1.1665

Cite as APA style citation

Derevyanko, O. (2019). Capitalization of food producers in the aspects of food safety. Food Industry Economics, 12(1), 20-27. doi: 10.15673/fie.v12i1.1665 